\title{
Higher Education Students' Preferences for Applying the Principles of Constructivism in Learning Programming Languages with the Use of ICTs
}

\author{
Al-Mothana M. Gasaymeh \\ Curriculum \& Instruction Department, Al-Hussein Bin Talal University, Ma'an, Jordan \\ E-mail: gasaymeh@gmail.com \\ Ibraheem A. AlJa'afreh \\ Curriculum \& Instruction Department, Al-Hussein Bin Talal University, Ma'an, Jordan \\ E-mail: ebraheem1_12@yahoo.com
}

Ayman Al-Dmour

College of Information Technology, Al-Hussein Bin Talal University, Ma'an, Jordan E-mail: ayman70jo@yahoo.com

Mohammad Abu Alrub

Curriculum \& Instruction Department, Al-Hussein Bin Talal University, Ma'an, Jordan E-mail: mohd_aboalrob@yahoo.com

Received: July 24, 2016 Accepted: August 21, 2016 Published: August 21, 2016

doi:10.5296/jse.v6i3.9780 URL: http://dx.doi.org/10.5296/jse.v6i3.9780

\begin{abstract}
This study investigated university students' preferences when the principles of constructivism are applied in their learning of programming languages with the use of information and communication technologies (ICTs) and the factors which influence these preferences. The respondents for this study were 193 students from three courses teaching programming languages in computer labs. A cross-sectional survey design was used. The study involved
\end{abstract}




\section{Macrothink}

one group of students who were taught programming languages based on the principles of constructivism and another group which was taught using the lecture-based teaching methods. At the end of the courses, data were collected through a questionnaire instrument that consisted of set of questions on a five-point Likert scale. The collected data were analyzed using descriptive statistics, t-tests, and ANOVA. The results show that in their learning of programming languages, the students had strong preferences for using each of the principles of constructivism considered in this study. The results showed that there were no significant differences in students' preferences regarding the use of constructivist principles based on gender, age, major, and prior experience in constructivist learning except for one scale. To maximize students' learning, students' preferences regarding the characteristics of the classroom learning environment should govern educational practice. The recommendations for higher education are related to educational practice as well as to ways of using ICTs to support university students' learning in general and to support the learning of programming languages in particular.

Keywords: Students' preferences, Constructivist learning, Principles of constructivism, Programming languages. 


\section{Introduction}

"Technology has changed the way we teach and the way we learn ... There is a close relationship between technology and constructivism" (Gilakjani, Lai-Mei, \& Ismail, 2013, p 49). Due to the popularity of using ICTs in education, the increasing relevance of constructivism has become one of the main trends in education (Chan, 2002, Oliver, 2002; Bailey \& Card, 2009). ICTs can be used to facilitate constructivist learning environment for teaching thinking skill in various academic disciplines and for various educational levels (Chan, 2002; Ng'ambi \& Johnston, 2006). Researchers have argued that the implementation of constructivist principles has the potential to improve the efficiency and effectiveness of teaching and learning (Pratton \& Hales, 1986; Santmire, Giraud, \& Grosskopf, 1999) and to prepare lifelong learners (Huang, 2002). Constructivist model of teaching on the college level would be more effective than the traditional approach, where the students would be more actively involved in the learning processes (Schell \& Janicki, 2013).

Institutions of higher education have focused on supporting faculty members and students to use different ICTs for educational purposes (Osika, Johnson, \& Butea, 2009). Faculty members have been provided with technological training and university students are familiar with the current versions of ICTs (Keengwe, Kidd, \& Kyei-Blankson, 2009; Roblyer, McDaniel, Webb, Herman, \& Witty, 2010). The widespread use of technologies for educational purposes among university students and faculty members requires pedagogical and instructional changes and support (Gilakjani et al, 2013). The principles of constructivism have been recommended as appropriate for shaping teaching and learning processes in educational environments that use ICTs (Oliver, 2002; Bailey \& Card, 2009; Schell\& Janicki 2013; Gilakjani et al, 2013).

Learning theories have a significant impact on educational practice in relation to the selection and shaping of instructional strategies, the use of media, and the role of the instructor. Different learning theories make different assumptions in regard to how learning occurs and the factors that influence learning. About 20 years ago, the appearance of ICTs as tools to support teaching and learning coincided with a growing responsiveness to, and identification of, different learning theories that rely on constructivist principles (Oliver, 2002). The constructivist approach of teaching has been considered as advantageous approach in the field of information systems. Nunes \& McPherson (2006) stated that:

The objectivist nature of lecture-based teaching is often perceived to be unsuitable for encouraging deep learning and the acquisition of contextualized transferable skills in the field of Information Systems. On the other hand, collaborative and active e-learning and online learning are seen to be an approach capable of fostering these highly desirable outcomes from the learning process. (p.1)

However, there is a need to examine whether students are ready for and would prefer the pedagogical changes that should accompany the use of ICTs in education. The current study examines Jordanian students' preferences regarding the application of the principles of constructivism in teaching programming languages with the use of ICTs. In addition, the study examined the relationships between students' preferences regarding the use of the 
principles of constructivism and their gender, age, major, academic year, and prior experience of constructivist learning.

\section{Constructivist Principles in Higher Education}

Learning based on constructivist principles emphasizes meaningful learning. Jonassen, Peck, and Wilson (1999) described the interrelated characteristics of meaningful learning. They reported that meaningful learning is active, constructive, intentional, authentic, and cooperative. In meaningful learning, learners should actively interact with the learning environment and construct their own interpretations of what they are observing (Jonassen et al, 1999). Learners combine a new understanding about the world with old ones (Jonassen et al, 1999). In order to construct their own mental models, learners formulate their learning goals, activities, decisions, strategies, and answers within the learning process (Jonassen et al, 1999). In meaningful learning, learning tasks should be real-world tasks such as case-based or problem-based learning activities (Jonassen et al, 1999), where constructivist teaching practice would focus on bridging the gap between school and work (Bunch, 2009). Learning tasks should be group-oriented activities that involve highly communicative interactions and social negotiations to reach a common understanding of what needs to be done and how to do it (Jonassen et al, 1999).

When using a constructivist approach of teaching (Jonassen, 1999; Jonassen, 2000), the principles of constructivism are applied to the educational process in the learning environment. This involves setting tasks that are based on questions, cases, problems, or projects. Students should be provided with different types of information, different cognitive tools, and different collaborative tools. Students should be able to observe and examine related cases which are similar to the educational tasks they are given. In addition, social and contextual support should be provided to the students. During the educational process, the different types of learning activities require instructional support. Such instructional support should be provided in the form of modeling, coaching, and scaffolding.

Constructivist learning implies that learners are the center of the learning process, where the goal of learning is to produce reflective thinkers and self-regulated learners who are able to take control of their own learning, learn from each other, apply their learning in different situations, and use metacognitive skills during their learning (Jonassen, Mayes, \& McAleese, 1993; Li, 2001; Jonassen, Howland, Moore, \& Marra, 2003 Kalpana, 2014). The instructor in constructivist learning acts as a collaborator, tutor, facilitator, encourager, and community builder rather than as a controller and transmitter of knowledge (Rovai, 2004).

Several research, that discuss the use of constructivism principles in teaching, (e.g., Jonassen, Davidson, Collins, Campbell, \& Haag, 1995; Jonassen, 1999; Jonassen, Carr, \& Yueh, 1998; Kanuka \& Anderson, 1999; Jonassen et al, 2003; Duffy \& Jonassen, 2013; Paily, 2013) has been devoted to examining the role of technology in supporting constructivist learning. This research has shown that technologies can play roles that are different to the conventional ones in transmitting knowledge to students. In constructivist learning, different ICTs should be used to: present the educational tasks in their actual contexts, engage learners in critical thinking about the educational content, maintain knowledge construction, support 
collaboration and cooperation, support investigation, facilitate learning by doing, allow for contextualized problem-solving, help to solve real-world problems, represent scholar partners that facilitate learning by reflecting, and provide students with different information resources.

Some studies have investigated university students' preferences in relation to constructivist learning in different environments in higher education: Online and face-to-face learning environments. Chen (2003) suggested in a theoretical study to follow a constructivist approach for teaching computer networking. In regard the teaching practices that apply constructivism to teaching computer networking, the author recommended:

using objects to build three-dimensional displays of networking concepts to promote discussion and clarification, using construction kits to allow students to raise questions and see their constructed concepts in action, building a friendly and safe learning atmosphere to encourage idea discussion and sharing, and supplying meaningful projects for students to bring in real-world experience.(p.25)

Nunes \& McPherson (2006) presented a theoretical study that suggested the use of constructivism in online learning of information systems. They proposed that constructivist e-learning require the tutor and the learners to obtain set of information, communication, social skills, and support of adequate learning resources that aligned with the constructivism principles.

In online environment and in the field of information system, Connolly and Begg, (2006) suggested in their study to follow a constructivist approach for teaching database analysis and design. The researchers followed constructivist teaching practice that rely on cognitive apprenticeship and project-based learning to teach two modules of database systems. Students' reactions were measured through the use of questionnaire. Students' feedbacks showed that they enjoyed the experience of using project-based learning. The participants believed that the teaching approach was better, more appealing, and more encouraging than traditional teaching methods. In addition, they believed that the approach bridged the gap between the course's educational materials and their potential future employment. However, the students complained about the extra work load and the issue of time management. In another research study, Neo (2005) examined students' attitudes toward online constructivist learning environment in Multimedia course. In this environment, the students were active learners who were working in groups to construct knowledge through solving a web-related problem. At the end of the course, students' reactions to such learning environment were measured using online survey, where one hundred and two students completed a questionnaire. The results showed that the participants were satisfied and positive regarding the learning environment. They believed that the constructivist learning environment allowed them to comprehend the educational problem collaboratively, to construct knowledge and to decide their own learning outcome.

Tsai (2008) examined university students' preferences for constructivist internet-based learning environments in Taiwanese universities. For the purposes of the study, 659 graduate and undergraduate students completed a questionnaire that measured their preferences for 
constructivist internet-based learning environments. The questionnaire asked respondents to rate the importance of seven scales, with each scale representing a feature of the constructivist learning environment. The scales were: relevance, multiple sources, challenge, student negotiation, cognitive apprenticeship, reflective thinking and epistemological awareness. The results showed that highest mean for the students' responses was for the relevance scale. This meant that the students liked to know the practical applications of their acquired knowledge in real life situations. The second- and the third-highest means were in the multiple sources scale and the reflective thinking scale. In constructivist internet-based learning environments, some students did not like difficult problem-solving tasks, and the lowest mean response was for the challenge scale. There were significant differences between female and male students in their means for three scales: challenging, cognitive apprenticeship, and epistemological awareness were higher for male students than for female students. Furthermore, Tsai (2008) compared students' preferences regarding constructivist internet-based learning environments based in their level of study. Compared to the undergraduate students in their first and second academic years, graduate students scored significantly higher in the scales student negotiation, cognitive apprenticeship, reflective thinking, and epistemological awareness. The results indicated that the majority of students preferred applying constructivist learning in internet-based learning environments, where the students tended to prefer relevant, flexible, multifaceted educational experiences.

In another study that focused on college of education, Liang and Tsai (2008) examined students' preferences in constructivist internet-based learning environments and the relationship of those preferences to their internet self-efficacy. In their study, 365 university students from the college of education in a Taiwanese university completed a cross-sectional questionnaire regarding their preferences toward constructivist internet-based learning environments and their internet self-efficacy. To rate each questionnaire item, respondents used a five-point Likert scale. The participants consisted of pre-service teachers and in-service teachers. The findings showed that the students reported strong preferences for the all the facets of constructivist internet-based learning environments, including: ease of use, relevance, multiple sources, student negotiation, inquiry learning, cognitive apprenticeship, critical judgment, and epistemological awareness. The results showed that internet self-efficacy had a direct effect on students' preferences regarding constructivist internet-based learning environments. In addition, the results showed that there were no significant differences between pre-service teachers' preferences and in-services teachers' preferences. The results showed significant differences in some aspects of students' preferences toward constructivist internet-based learning environments based on age. Older students scored higher on the ease-of-use, cognitive apprenticeship, and epistemological awareness scales. The current study investigates in-class learning environments rather than internet-based learning environments. It focuses on using constructivist principles in a specific academic discipline: programming languages.

Some studies have examined the benefits of applying the principles of constructivism in higher education and students' preferences regarding constructivist learning in traditional face-to-face settings. For instance, Neo, Neo, \& Xiao-Lian,(2007) conducted a study that 
aimed to examine the perspectives of the university Malaysian students' toward the use of constructivist approach to teach in an interactive multimedia course. Fifty three students from different faculties were enrolled in face-to-face course. The course lasted for fourteen weeks. The approach involved having the students working in groups to solve multimedia design problems. The instructor acted as facilitator of the learning process. At the end of the course, students' opinions were measured using questionnaire and interviews, The results showed that the students believed the constructivist approach in their learning made them more engaged in the learning process, more motivate to accomplish the learning tasks, and more creative in their design of the multimedia project. The students believed the teaching approach was encouraging and supporting. Furthermore, the students believed that the constructivist approach helped in bridging the gap between the theory and the practice in the real life world in relation to multimedia designing.

Neo and Neo (2009) examined students' perceptions of constructivist learning in an interactive multimedia course in a university in Malaysia. The students worked in groups in a project-based learning environment for one semester. After the completion of the project, the 53 participants reflected on their learning. The students worked in groups of 4 to 5 . At the end of the semester, students' perceptions were canvassed using a questionnaire. The results showed that the students believed that the constructivist learning approach enhanced their motivation and interest in doing the project. In addition, the students reported that the constructivist learning approach increased their understanding of the content domain of the project. The students responded favorably to working in teams, and reported that they enjoyed working in groups. Furthermore, the students believed that the constructivist learning approach improved their learning skills, including critical thinking, creativity, teamwork, and communication and presentation skills. The researchers concluded that "incorporating multimedia technology into a constructivist learning environment can lead to innovative teaching and learning methods for the improvement of classroom learning" (p.65).

In a another recent study, Hussain (2012) examined the significance of a constructivist approach at the higher education level. The researcher used his own observation as a data collection method. Thirty-two students in a qualitative research methods course from a college of education at a university in Pakistan participated in the study. A constructivist approach was used for teaching the students for one semester. The constructivist approach involved designing activities that were skills-oriented and were offered to students in groups. In addition, several educational resources were provided to the students. The instructions involved showing the students how to apply what they learnt in the class in real life situations through the use of case studies. In addition, discussions in relation to the class topics were encouraged. The results revealed that the students gradually came to like the idea of constructing their own knowledge and applying it in practical situations. In addition, the participants liked being independent learners and relying less on the instructor. They liked to work in groups, where they supported each other and learned from each other. The students participated in discussions and expressed their points of view, and they appreciated the instructor's feedback. Furthermore, the constructivist approach improved students' social relationships and communication. 
The previous studies examined students' reactions to the use of constructivist learning principles with the use of and without the use of technology. Some of these research studies have recommended the use constructivist teaching approach in teaching different aspects of computer science in traditional and online learning environments. Different from these findings, Wulf (2005) argued that some university students would complain about constructivist approach in teaching computer programming, where the students would prefer greater role of instructor in the educational process. The previous students showed that a range of factors affect students' preferences in constructivist learning. Furthermore, the previous studies did not examined the differences of students preferences of constructivist approach based on their characteristics e.g., age, major, academic year, and prior experience of constructivist learning.

In the Arab world in general and in Jordan in particular, while studies (Simsim, 2011; Qudah, Hussain, \& Al Matari, 2013; Al-Asmari \& Khan, 2014) have shown that students had favorable attitudes and perceptions toward the the use of technology in their education, there is a shortage of studies examining students' preferences regarding the accompanying shift in educational practices such as employing the principles of constructivism when using ICTs.

\section{Purpose of the Study}

The purpose of the study was to examine students' preferences when applying the principles of constructivism in teaching programming languages with the use of ICTs. In addition, the study examined the relationships between students' preferences and their gender, age, major, academic year, and prior experience of constructivist learning.

The research questions for this study were:

1) What are university students' preferences for applying the principles of constructivism when learning programming languages with the use of ICTs?

2) What are the differences (if any) between participants' preferences in the use of constructivism in learning programming languages based the following variables:

- gender

- age

- major

- $\quad$ academic year

- experiencing constructivist learning.

\section{Method}

The study used a cross-sectional survey design. The participants completed a questionnaire that aimed to examine their preferences for applying the principles of constructivism in their learning of programming languages with the use of ICTs. 


\subsection{Participants}

The respondents were 193 students from three programming language courses. The first course was for working teachers in a postgraduate diploma program. The second class was offered to undergraduate students in a teacher program. The third course was offered to undergraduate students from different majors. The three courses were taught in technology rich environments, where each student had his/her own computer with an internet connection in a computer lab. The participants included 100 female students and 88 male students, while five students did not answer the gender question. Nearly half of the students $(47.7 \%, n=92)$ were between the ages of 18 and 22, the average age of the undergraduate students. About three-quarters of the participants were from the colleges of education, literature and the arts, and business administration and economics. The remaining quarter was from colleges of science, information technology, and nursing. About two-thirds of the participants were in their first and fourth academic years, and nearly one-third were in their second and third academic years. Only ten students were in their fifth academic year. Eighty-three of the students were in courses that applied the principles of constructivism in teaching programming languages with the use of ICTs. The remaining 110 students were in courses that followed conventional teaching. Table 1 shows a summary of participants' characteristics. 


\section{Macrothink}

Table 1. Descriptive summary of participants' characteristics

\begin{tabular}{|c|c|c|c|}
\hline Variables & Category & Number & Percentage \\
\hline \multirow[t]{2}{*}{ Gender } & Male & 88 & 46.8 \\
\hline & Female & 100 & 53.2 \\
\hline \multirow[t]{5}{*}{ Age } & $18-22$ & 92 & 47.7 \\
\hline & $23-28$ & 43 & 22.3 \\
\hline & $29-33$ & 25 & 13.0 \\
\hline & $34-38$ & 17 & 8.8 \\
\hline & $<38$ & 8 & 4.1 \\
\hline \multirow[t]{7}{*}{ Major } & Education & 43 & 22.3 \\
\hline & Literature and Arts & 55 & 28.5 \\
\hline & Science & 6 & 3.1 \\
\hline & Business Administration \& & 48 & 24.9 \\
\hline & Economics & 14 & 7.3 \\
\hline & Information Technology & 6 & 3.1 \\
\hline & Nursing & & \\
\hline \multirow[t]{5}{*}{ Academic Year } & 1 & 63 & 32.6 \\
\hline & 2 & 18 & 9.3 \\
\hline & 3 & 37 & 19.2 \\
\hline & 4 & 60 & 31.1 \\
\hline & 5 & 10 & 5.2 \\
\hline \multirow{2}{*}{$\begin{array}{l}\text { Experience with } \\
\text { constructivism }\end{array}$} & Yes & 83 & 43 \\
\hline & No & 110 & 57 \\
\hline
\end{tabular}

\subsection{Instruments}

The data collection instrument in this study was a questionnaire. The questionnaire was designed by the researchers based on previous constructivist learning research (e.g., Jonassen etal, 1995; Jonassen, 1996; Jonassen et al, 1998; Neo \& Neo, 2009; Jonassen et al, 2003; Tsai 2008; Liang \& Tsai, 2008; Hussain, 2012; Duffy \& Jonassen, 2013). The questionnaire was made up of question items (variables) and each item is measured on a 5-point Likert scale. The items were grouped in five scales:

1) Relevance educational subject scale: This scale measured the extent to which students preferred that the subject was presented as a real-life problem that the students might face in their future jobs. ('I prefer lessons that use multimedia and educational software for simulations and videos that present the educational problem in its real context.') 
2) Related cases scale: This scale measured the extent to which students preferred that the lessons involved providing them with cases (and solutions) related to the problem they were investigating. ('I prefer lessons in which simulation applications are used to simulate similar cases and their solutions.')

3) Information resources scale: This scale measured the extent to which students preferred that the lesson involved providing them with different types of information resources. ('I prefer lessons that involve using the internet as a tool for gathering information.')

4) Collaborative learning scale: This scale measured extent to which students preferred that the lessons involved working in groups. ('I prefer lessons in which I can use chat and social media sits to communicate with other students in relation to subject.')

5) Role of the instructor scale: This scale measured the extent to which students preferred lessons in which the instructor played the role of facilitator rather than controller of the educational process. ('I prefer the lesson in which the faculty member acts as a mentor in the learning process, rather than playing a dominant role'.)

The questionnaire instrument' validity was checked through panel of experts. Three professors majored in instructional technology, measurements and evaluation, and curriculum and instruction reviewed the instrument and provided some adjustments. The reviewers' comments were considered in improving the instrument. Cronbach's alpha was used as measure of the instrument's reliability, the value of Cronbach's alpha for the instrument was greater than 0.7 .

\subsection{Procedures}

The study took place in the 2013/2014 and 2015/2016 academic years. Some of the students were in classes that followed the principles of constructivism in teaching programming languages, while other students were in classes that depended on direct instruction for learning programming languages.

In the direct instruction classes, the instructors followed conventional ways of teaching or in which they would stand in front of a classroom and present the information. In the constructivist classes, the instructors used problem-based learning in which the learners were required to solve programming problems. Throughout the semester, the instructor presented to the students a set of programming problems that they might encounter in their future jobs. The instructor used videos and simulations to present the educational subjects. In addition, the instructor provided the students with a set of related cases that helped beginner students, who lacked experience, to understand and solve the problem. The related cases and their solutions were provided to the students using videos and simulations. In addition to the related cases, the instructor provided the students with different resources for accessing information, including websites, instructional software, and videos. The information resources were related to the topic and could be used to solve the programming problems. The students were encouraged to work in groups to solve the programming problems. They 
used different electronic services to work together in and out of the class.

The data were collected from three programming languages classes over two semesters using a paper-based questionnaire with five sections. Two of the classes followed the principles of constructivism, while the other used direct instruction.

\subsection{Data Analysis}

Analysis of questionnaire data included descriptive analysis and comparison of means. Descriptive statistics that included means and standard deviations were used to answer the first research question regarding students' preferences in the use of the principles of constructivism in learning programming languages. T-tests were used to examine the differences between participants' preferences in the use of the principles of constructivism in their learning of programming languages based on their gender and the extent of their experience with constructivism. Analysis of Variance (ANOVA) was used to compare the means of students' preferences based on their age, major, and academic year. However, the t-test requires assumption of normality, and the ANOVA require assumptions of normality, Independence of cases, and homoscedasticity. Therefore, prior to conducting the statistical analysis, these assumptions were verified. The statistical analysis software SPSS 16.0 was used for the analysis.

\section{Results}

\subsection{Students' Preferences in the of Use of the Principles of Constructivism}

Table 2 shows the students' means and standard deviations on the five scales of the questionnaire that measured students' preferences in the use of the principles of constructivism. The means of students' responses on each of the five-point Likert scales of the questionnaire were all greater than three, with an overall average that was close to four $(M=3.75, S D=.45)$. The results indicated that the students had positive perceptions regarding the use of each of the principles of constructivism. They scored highest on the related cases scale $(M=4.10, S D=.48)$, implying that they preferred to be provided with solutions to similar cases to help them understand the topic. In addition, the students had higher scores on the relevance scale $(\mathrm{M}=3.93, \mathrm{SD}=.56)$ and the role of the instructor scale $(M=3.88, S D=.72)$, suggesting that they preferred to have their subjects represented in real life contexts, and they preferred to take responsibility for their education by limiting the role of instructor to that of a facilitator. On the other hand, the students scored lowest on the collaborative learning scale $(M=3.30, S D=.59)$ and the information resources scale $(M=$ 3.53, $S D=.52$ ), indicating that some students preferred to work individually rather than collaboratively and they liked to use a limited number of information resources rather than a wide range of resources. 
Table 2. Means and standard deviations of participants' responses to questionnaire scales

\begin{tabular}{llcccc}
\hline & $\mathrm{N}$ & $\begin{array}{c}\text { \# of } \\
\text { Items }\end{array}$ & Mean & STD \\
\hline 1 & $\begin{array}{l}\text { Relevance educational subject scale (Relevance). } \\
2\end{array}$ & 194 & 5 & 3.93 & .56 \\
$\begin{array}{l}\text { Related cases scale. (Related cases) } \\
\text { Information resources scale.( Information }\end{array}$ & 194 & 5 & 4.10 & .48 \\
$\begin{array}{l}\text { resources) } \\
4\end{array}$ & 194 & 8 & 3.53 & .52 \\
$\begin{array}{l}\text { Collaborative learning scale. (Collaborative) } \\
\text { Role of the instructor scale. (Role of the } \\
\text { instructor) }\end{array}$ & 194 & 9 & 3.30 & .59 \\
& Average. & 194 & 34 & 3.75 & .35 \\
\hline
\end{tabular}

5.2 Students' Preferences in the Use of the Principles of Constructivism based on their Gender

Table 3 shows the differences between the means for female and male students for the five scales of the questionnaire. Female participants $(M=4.17, S D=.46)$ achieved significantly higher scores on the related cases scores than male students $(M=4.03, S D=.49), \mathrm{t}(186)=$ $2.07, \mathrm{p}<.05$. This indicated that the female students were more likely to want to be provided with solutions to similar cases to help them understand the topic. Practitioners in higher education should give attention to this preference when applying the principles of constructivism for teaching programming languages to female students.

However, the results showed that there were no significant differences between male and female students' scores for any of the other scales, or for the overall scales average. The results indicated that female students and male students had similar preferences for most of the principles of constructivism in their learning of programming languages.

Table 3. Results of T-tests and descriptive statistics of questionnaire scales by gender

\begin{tabular}{|c|c|c|c|c|c|c|c|c|c|}
\hline \multirow[t]{3}{*}{ Scales } & \multicolumn{6}{|c|}{ Groups } & \multirow[b]{3}{*}{$t$} & \multirow[b]{3}{*}{$d f$} & \multirow[b]{3}{*}{$p$} \\
\hline & \multicolumn{3}{|l|}{ Female } & \multicolumn{3}{|c|}{ Male } & & & \\
\hline & $M$ & $S D$ & $n$ & $M$ & $S D$ & $n$ & & & \\
\hline Relevance & 3.98 & .54 & 100 & 3.86 & .58 & 88 & 1.49 & 186 & .14 \\
\hline Related cases & 4.17 & .46 & 100 & 4.03 & .49 & 88 & 2.07 & 186 & .04 \\
\hline Information resources & 3.57 & .49 & 100 & 3.49 & .56 & 88 & 1.14 & 186 & .26 \\
\hline Collaborative & 3.25 & .56 & 100 & 3.35 & .64 & 88 & -1.21 & 186 & .23 \\
\hline Role of the instructor & 3.88 & .45 & 100 & 3.91 & .95 & 88 & -.21 & 186 & .83 \\
\hline Average & 3.77 & .31 & 100 & 3.73 & .40 & 88 & .86 & 186 & .39 \\
\hline
\end{tabular}

$* p<.05$

\subsection{Students' Preferences in the Use of the Principles of Constructivism Based on Age}

Table 4 shows the results of a one-way ANOVA that was used to compare students' preferences based on their age. The results show no significant differences based on age. This 
suggests that the students had strong preferences for the use of each of the principles across all ages.

Table 4. Results of one-way ANOVA for students' responses to questionnaire scales based on age

\begin{tabular}{llll}
\hline Outcome & $d f$ & $F$ & $p$ \\
\hline Relevance scale & 4 & .12 & .98 \\
Related cases & 4 & .31 & .87 \\
Information resources & 4 & .82 & .51 \\
Collaborative & 4 & 1.06 & .38 \\
Role of the instructor & 4 & .25 & .91 \\
Average & 4 & .49 & .75 \\
\hline
\end{tabular}

Note. 1 = "18-22 years old", 2 = "23-28 years old", 3 = "29-33 years old", 4 = "34-38 years old ", $5="<38$ years old".

5.4 Students' Preferences for the Use of the Principles of Constructivism Based on their Major

Table 5 shows the results of a one-way ANOVA that was used to compare students' preferences based on thier major. The results show that none of students' responses differed based on their majors. This suggests that the students from all disciplines, approved of the use of each of the principles of constructivism in their programming language learning.

Table 5. Results of one-way ANOVA for students' responses to questionnaire scales by major

\begin{tabular}{llll}
\hline Outcome & $d f$ & $F$ & $p$ \\
\hline Relevance scale & 5 & 1.46 & .21 \\
Related cases & 5 & 1.98 & .08 \\
Information resources & 5 & .86 & .51 \\
Collaborative & 5 & 1.10 & .36 \\
Role of the instructor & 5 & 1.35 & .25 \\
Average & 5 & 1.53 & .18 \\
\hline
\end{tabular}

Note. 1 = " Education", 2 = " Literature and Arts", 3 = " Science", $4=$ " Business Administration \& Economics", 5=" Information Technology", 6="Nursing".

5.5 Students' Preferences in the Use of the Principles of Constructivism Based on Academic Year

Table 6 shows the results of a one-way ANOVA that was used to compare students' preferences based on their academic year. The results show that none of students' responses differed based on their academic year. This suggests that the students approved of the use of each of the principles of constructivism regardless of their academic year in the university. 


\section{Ml Macrothink}

Table 6. Results of one-way ANOVA for students' responses to questionnaire scales by academic year

\begin{tabular}{llll}
\hline Outcome & $d f$ & $F$ & $p$ \\
\hline Relevance scale & 4 & .70 & .59 \\
Related cases & 4 & .22 & .93 \\
Information resources & 4 & 1.62 & .17 \\
Collaborative & 4 & 1.58 & .18 \\
Role of the instructor & 4 & .68 & .61 \\
Average & 4 & 1.09 & .36 \\
\hline
\end{tabular}

Note. 1 = "first year", 2 = "second year", 3 = "third year ", 4 = "fourth year", 5="fifth year ".

5.6 Students' Preferences in the Use of the Principles of Constructivism Based on prior Experience with Constructivism

Table 7 shows that the differences in the means for the scores on the five scales of the questionnaire for the students who had experience with constructivism and the students who had no experience with constructivism. The results show that there were no significant differences for any of the scales and for the overall scales average. The results indicate that experience with constructivism did not influence students' preferences regarding the principles of constructivism in their learning of programming languages.

Table 7. Results of T-tests and descriptive statistics of questionnaire scales by prior experience with constructivism

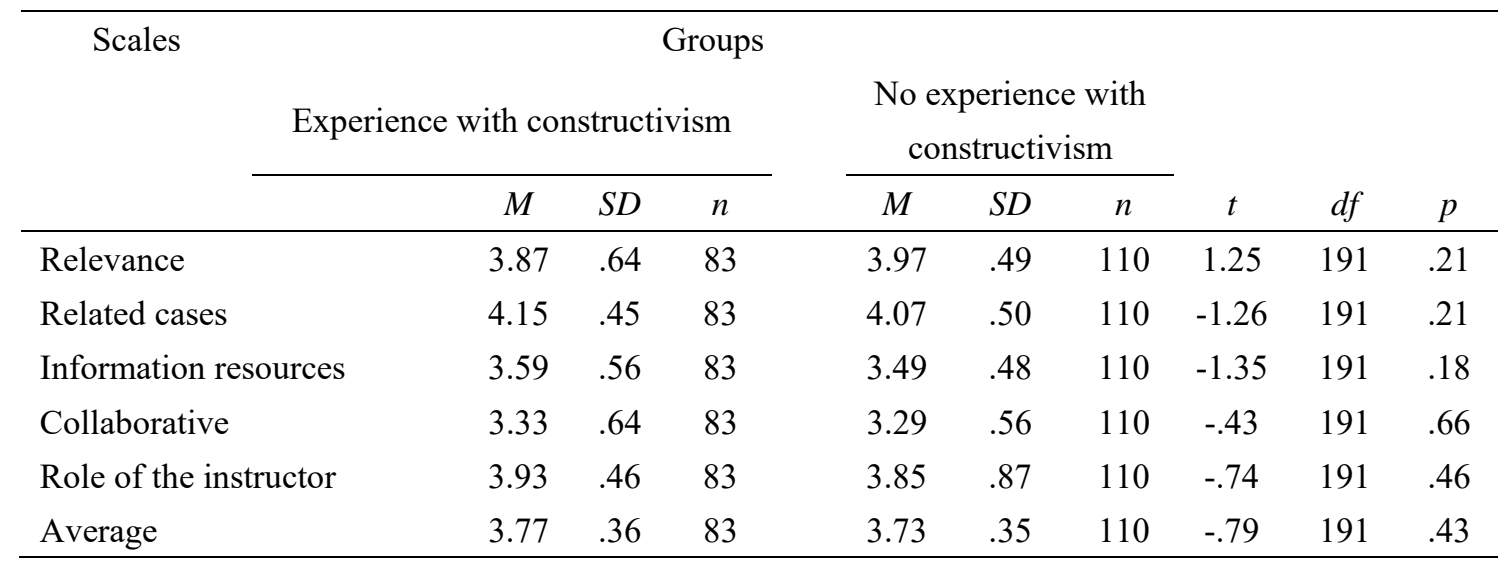

\section{Discussion and Conclusion}

Based on a data collected from 193 university students, this study examined students' preferences regarding the use of the principles of constructivism in their learning of programming languages. Students' preferences were measured using a questionnaire with five scales: relevance, related cases, information resources, collaborative, and the role of the instructor. Generally, the results showed that students had high scores in these scales. Further investigation was performed to assess the differences in students' preferences regarding the use of constructivism based on gender, age, major, academic year, and experience. The results showed that there were no significant differences of their preferences in the use of the 
principles of constructivism based on these variables except for one scale: female students were more likely to want to be provided with solutions to similar cases to help them understand the topic.

These results are similar to the findings in other studies (Neo, 2005; Connolly \& Begg, 2006; Neo, Neo, \& Xiao-Lian, 2007; Tsai, 2008; Liang \& Tsai, 2008; Neo \& Neo, 2009; Hussain, 2012). The findings indicate that Jordanian students have positive perceptions of the use of constructivist principles when learning programming languages using ICTs. Jordanian university students had positive perceptions and experiences of ICTs and its implications in their education (Al-Adwan, Al-Adwan, \& Smedley, 2013; Bsharah, Gasaymeh, \& Abdelrahman, 2014), such positive perceptions and experiences might positively affect their preferences of the use of the principles of constructivism that rely on the use of ICTs to apply such principles in the educational practice.

To maximize students' learning, students' perceptions and preferences regarding the characteristics of the classroom learning environment should set the tone of educational practice. The findings provided several recommendations for educators in higher education. These recommendations are related to educational practice as well as to the ways of using ICTs to support university students' learning in general and in the learning of programming languages in particular. The findings suggest that university educators should focus on the use of the principles of constructivism in their educational practice. Educators should present the learning of programming languages in the form of real-life problems and relate educational tasks to realistic situations. Students should be provided with cases and solutions which are similar to the real-life problems they are being asked to solve. University educators should provide students with multiple information sources to resolve the presented real-life problems rather than relying only on textbooks. The educators should facilitate teams to work towards getting through the educational tasks. In addition, the educators should allow the students to take responsibility for their learning, and the educators should play the role of facilitator.

The other recommendations for practice are related to the to the ways of using ICTs to support university students' learning in general and the learning of programming languages in particular. Various types of ICTs can be used to support students' learning based on their preferences regarding the use of the principles of constructivism. For instance, simulation, videos and narratives can be used to present the topics as real-life problems. In addition, these technologies can be used to provide students with similar cases and solutions to the problem cases they are asked to solve. ICTs provide authoritative resources for learners, these resources may include static and dynamic visuals, sound resources and internet resources that can be accessed via their computers and mobile phones. Furthermore, ICTs may play a major role in creating and enhancing collaboration among students, especially out of class. The collaboration technologies include electronic mail, computers, mobile conferencing software, learning management systems and social media sites. University educators can use ICTs to enable students to take responsibility of their learning and to limit their own role to that of encourager and community builder rather than controller and transmitter of knowledge. Educators can provide students with different electronic information resources, electronic collaboration tools, and cognitive tools such as databases, semantic networks, spreadsheets, 
expert systems, system modeling tools, micro- worlds, intentional information search engines, visualization tools, multimedia publishing tools, live conversation environments, and computer conferences (Jonassen, 1999).

The findings contribute to the body of knowledge on the use of learning theories to guide educational practice in terms of students' preferences. The current study has shown that students of different ages, majors, academic years, and prior experience with constructivism all had strong preferences for the use of the principles of constructivism in their learning of programming languages. Further investigations are required in different study settings, educational topics, study samples, sampling procedures, and data collection methods. In addition, future study can be conducted to address the outcome assessment under each treatment i.e., the success of learning a programming language in traditional learning environment versus constructivist learning environment.

\section{References}

Al-Adwan, A., Al-Adwan, A., \& Smedley, J. (2013). Exploring students acceptance of e-learning using Technology Acceptance Model in Jordanian universities. International Journal of Education and Development using Information and Communication Technology, 9(2), 4.

Al-Asmari, A. M., \& Rabb Khan, M. S. (2014). E-learning in Saudi Arabia: Past, present and future. Near and Middle Eastern Journal of Research in Education, 2.

Bailey, C. J., \& Card, K. A. (2009). Effective pedagogical practices for online teaching: Perception of experienced instructors. The Internet and Higher Education, 12(3), 152-155. http://dx.doi.org/10.1016/j.iheduc.2009.08.002

Bsharah, M., Gasaymeh, A. M., \& Abdelrahman, M. B. (2014). The Relationship between the Use of Social Networking Sites (SNS) and Perceived Level of Social Intelligence among Jordanian University Students: The Case of Facebook. International Journal of Psychological Studies, 6(3), 1. http://dx.doi.org/10.5539/ijps.v6n3p1

Bunch, J. M. (2009). A constructivist approach to teaching web development in post-secondary vocational settings. Journal of Information Technology Education, 8(1), 257-271.

Chan, D. (2002). The Role of ICT in a Constructivist Approach To the Teaching of Thinking Skills, Ngee Ann Polytechnic. Retrieved October, 4, 2016.

Chen, C. (2003). A constructivist approach to teaching: Implications in teaching computer networking. Information Technology, Learning, and Performance Journal, 21(2), 17.

Connolly, T. M., \& Begg, C. E. (2006). A constructivist-based approach to teaching database analysis and design. Journal of Information Systems Education, 17(1), 43.

Duffy, T. M., \& Jonassen, D. H. (Eds.). (2013). Constructivism and the technology of instruction: A conversation. Routledge.

Gilakjani, A. P., Lai-Mei, L., \& Ismail, H. N. (2013). Teachers' use of technology and constructivism. International Journal of Modern Education and Computer Science, 5(4), 49. 
Huang, H. M. (2002). Toward constructivism for adult learners in online learning environments. British Journal of Educational Technology, 33(1), 27-37. http://dx.doi.org/10.1111/1467-8535.00236

Hussain, I. (2012). Use of constructivist approach in higher education: An instructors' observation. Creative Education, 3(02), 179. http://dx.doi.org/10.4236/ce.2012.32028

Jonassen, D. (1999). Designing Constructivist Learning Environments. In C. M. Reigeluth (Ed.), InstructionalDesign Theories and Models: A New Paradigm of Instructional Theory, Vol. II (pp. 215-239). Mahwah, NJ:Lawrence Erlbaum Associates.

Jonassen, D., Davidson, M., Collins, M., Campbell, J., \& Haag B.B. (1995). Constructivism and computer-mediated communication in distance education. American Journal of Distance Education, 9(2), 7-26. http://dx.doi.org/10.1080/08923649509526885

Jonassen, D.,Mayes, T., \& McAleese, R. (1993). A manifesto for a constructivist approach to uses of technology in higher education. In T. Duffy,J. Lowyck, \& D. Jonassen (Eds.), Designing Environments for Constructivist Learning (pp. 231-247). Berlin Heidelberg: Springer-Verlag.

Jonassen, D.H. (2000). Revisiting Activity Theory as a Framework for Designing Student-Centred Learning Environments. In D.H. Jonassen, \& S.M.Land(eds), Theoretical Foundations of Learning Environments. NJ: Lawrence Erlbaum

Jonassen, D.H., Carr, C., \& Yueh, H. (1998). Computers as mindtools for engaging learners in critical thinking. TechTrends, 43(2), 24-32. http://dx.doi.org/10.1007/BF02818172

Jonassen, D.H., Howland, J., Moore, J, \& Marra, R.M. (2003). Learning to solve problems with technology: A constructivist perspective, 2nd Edition. Columbus, $\mathrm{OH}$ : Merrill/Prentice-Hall.

Jonassen, D.H., Peck, K.L., \& Wilson, B.G. (1999). Learning with technology. Upper SaddleRiver, NJ: Prentice Hall.

Kalpana, T. (2014). A constructivist perspective on teaching and learning: A conceptual framework. International Research Journal of Social Sciences, 3(1), 27-29.

Kanuka, H., \& Anderson, T. (1999). Using constructivism in technologymediated learning: Constructing order out of the chaos in the literature. Radical Pedagogy, 2(1). Retrieved April, 4, 2016.

Keengwe, J., Kidd, T., \& Kyei-Blankson, L. (2009). Faculty and technology: Implications for faculty training and technology leadership. Journal of Science Education and Technology, 18(1), 23-28. http://dx.doi.org/10.1007/s10956-008-9126-2

Li, W. (2001). Constructivist learning systems: A new paradigm. In Advanced Learning Technologies, 2001. Proceedings. IEEE International Conference on (pp. 433-434). IEEE.

Liang, J.C., \& Tsai, C.C. (2008). Internet self-efficacy and preferences toward constructivist Internet-based learning environments: A study of pre-school teachers in Taiwan. Educational Technology \& Society, 11(1), 226-237.

Neo, M. (2005). Web-enhanced learning: engaging students in constructivist learning. Campus-Wide Information Systems, 22(1), 4-14. 
Neo, M., \& Neo, T. K. (2009). Engaging Students in Multimedia-mediated Constructivist Learning-Students' Perceptions. Educational Technology \& Society, 12(2), 254-266.

Neo, M., Neo, T. K., \& Xiao-Lian, G. T. (2007). A Constructivist Approach to Learning an Interactive Multimedia Course: Malaysian Students' Perspectives. Australasian Journal of Educational Technology, 23(4), 470-489. http://dx.doi.org/10.14742/ajet.1247

Ng'ambi, D., \& Johnston, K. (2006). An ICT-mediated Constructivist Approach for increasing academic support and teaching critical thinking skills. Educational Technology \& Society, 9(3), 244-253.

Nunes, M., \& McPherson, M. (2006). Learning support in online constructivist environments in information systems. Innovation in Teaching and Learning in Information and Computer Sciences, 5(2), 1-9. http://dx.doi.org/10.11120/ital.2006.05020006

Oliver, R. (2002). The role of ICT in higher education for the 21 st century: ICT as a change agent for education. Retrieved October, 4, 2016.

Osika, E., Johnson, R., \& Butea, R. (2009). Factors influencing faculty use of technology in online instruction: A case study. Online Journal of Distance Learning Administration, 12(1).

Paily, M. U. (2013). Creating Constructivist Learning Environment: Role of" Web 2.0" Technology. International Forum of Teaching and Studies 9 (1): 39-50.

Pratton, J., \& Hales, L. W. (1986). The effects of active participation on student learning. $\begin{array}{llll}\text { Journal of Educational 210-215. } & \text { Research, }\end{array}$ http://dx.doi.org/10.1080/00220671.1986.10885679

Qudah, K. Y., Hussain, J. A., \& Al Matari, R. (2013). Students' Attitudes in Colleges of Education at the Jordanian Universities towards Mobile Phone Usage in University Education. iJIM, 7(2), 19-28. http://dx.doi.org/10.3991/ijim.v7i2.2286

Roblyer, M. D., McDaniel, M., Webb, M., Herman, J., \& Witty, J. V. (2010). Findings on Facebook in higher education: A comparison of college faculty and student uses and perceptions of social networking sites. The Internet and higher education, 13(3), 134-140. http://dx.doi.org/10.1016/j.iheduc.2010.03.002

Rovai, A. P. (2004). A constructivist approach to online college learning. The Internet \& Higher Education, 7(2), 79-93. http://dx.doi.org/10.1016/j.iheduc.2003.10.002

Santmire, T. E., Giraud, G., \& Grosskopf, K. (1999). An experimental test of a constructivist educational environment. Annual Meeting of the American Educational Research Association, Montreal, 19-23 .

Schell, G., \& Janicki, T. J. (2013). Online course pedagogy and the constructivist learning model. Journal of the Southern Association for Information Systems, 1(1). http://dx.doi.org/10.3998/jsais.11880084.0001.104

Simsim, M. T. (2011). Internet usage and user preferences in Saudi Arabia. Journal of King Saud University-Engineering Sciences, 23(2), 101-107. http://dx.doi.org/10.1016/j.jksues.2011.03.006

Tsai, C. C. (2008). The preferences toward constructivist Internet-based learning environments among university students in Taiwan. Computers in Human Behavior, 24(1), 16-31. http://dx.doi.org/10.1016/j.chb.2006.12.002 
Wulf, T. (2005, October). Constructivist approaches for teaching computer programming. In Proceedings of the 6th conference on Information technology education (pp. 245-248). ACM. 